\title{
Expression of tumor-associated glycoprotein-72 (TAG-72) antigen in human prostatic adenocarcinomas.
}

\author{
Dev Karan \\ University of Nebraska Medical Center \\ Sonny L. Johansson \\ University of Nebraska Medical Center, sjohanss@unmc.edu \\ Ming-Fong Lin \\ University of Nebraska Medical Center, mlin@unmc.edu \\ Surinder K. Batra \\ University of Nebraska Medical Center, sbatra@unmc.edu
}

Tell us how you used this information in this short survey.

Follow this and additional works at: https://digitalcommons.unmc.edu/com_bio_articles

Part of the Medical Biochemistry Commons, and the Medical Molecular Biology Commons

\section{Recommended Citation}

Karan, Dev; Johansson, Sonny L.; Lin, Ming-Fong; and Batra, Surinder K., "Expression of tumor-associated glycoprotein-72 (TAG-72) antigen in human prostatic adenocarcinomas." (2001). Journal Articles:

Biochemistry \& Molecular Biology. 30.

https://digitalcommons.unmc.edu/com_bio_articles/30

This Article is brought to you for free and open access by the Biochemistry \& Molecular Biology at DigitalCommons@UNMC. It has been accepted for inclusion in Journal Articles: Biochemistry \& Molecular Biology by an authorized administrator of DigitalCommons@UNMC. For more information, please contact digitalcommons@unmc.edu. 


\title{
Expression of tumor-associated glycoprotein-72 (TAG-72) antigen in human prostatic adenocarcinomas
}

\author{
DEV KARAN ${ }^{1}$, SONNY L. JOHANSSON ${ }^{2}$, MING-FONG LIN ${ }^{1,2,3}$ and SURINDER K. BATRA ${ }^{1,2}$ \\ ${ }^{1}$ Department of Biochemistry and Molecular Biology, ${ }^{2}$ Department of Pathology and Microbiology and \\ Eppley Institute for Research in Cancer and Allied Diseases, ${ }^{3}$ Department of Surgery, Section of Urology, \\ University of Nebraska Medical Center, Omaha, NE, USA
}

Received April 9, 2001; Accepted May 26, 2001

\begin{abstract}
Tumor-specific antigens are usually defined by monoclonal antibodies (MAbs) and can play critical roles in the diagnosis and therapy of carcinomas. Despite advances in the understanding of the molecular genetics of human prostate carcinomas, therapeutic approaches require that tumor-specific markers, preferably on the cell surface, should be defined. In this study, we examined the expression of an oncofetal antigen tumor-associated glycoprotein-72 (TAG-72) in prostatic adenocarcinomas with a Gleason grade of six or higher. Using a second generation MAb CC49 against TAG-72, immunoreactivity was detected in $88 \%$ (29/33) of the prostatic cancer tissues. Occasionally, the benign epithelium showed a very faint immunostaining but in most of the specimens, no reactivity was detected. Positive staining was present in the cytoplasm and the cell membrane of the malignant cells similar to reports on other cancer tissues. A weaker staining pattern of this antigen was seen in poorly differentiated areas. A significant negative correlation $(\mathrm{r}=-0.36, \mathrm{p}<0.05)$ was observed between TAG-72 antigen expression and Gleason grade. The TAG-72 antigen expression in prostatic adenocarcinomas may be used as a target for radioimmunotherapy by the multivalent single chain antibody CC49 constructs recently generated by our group.
\end{abstract}

\section{Introduction}

Prostate cancer is the most common malignancy in the Western male populations. It is often an indolent disease but approximately $25-30 \%$ of the tumors behave aggressively resulting in approximately 40,000 deaths annually in the United States (1). In the majority of the aggressive cases, the tumor ultimately becomes androgen-independent. Patients with metastatic adenocarcinoma are frequently treated with

Correspondence to: Dr Surinder K. Batra, Department of Biochemistry and Molecular Biology, 984525 University of Nebraska Medical Center, Omaha, NE 68198-4525, USA

E-mail: sbatra@unmc.edu

Key words: Gleason grade, immunohistochemistry, monoclonal antibody CC49, prostatic adenocarcinoma, TAG-72 chemical or surgical androgen ablation therapy. However, at the time of diagnosis, almost $33 \%$ of the patients have the advanced disease stage (2). Therefore, identification of tumor markers that are useful in the diagnosis and follow-up of patients with prostate cancer is a major task. Potential candidates, such as PSA (Prostate Specific Antigen), have not been successful in imaging trials, probably due to the fact that this antigen is a secreted protein (3). Some patients in whom conventional therapy has failed have been treated with radiolabeled $\mathrm{CC} 49$ against the tumor maker tumor-associated glycoprotein-72 (TAG-72) (4).

The TAG-72 is a high molecular weight glycoprotein related to the sialyted $\mathrm{Tn}$ antigen, and is frequently expressed in a variety of adenocarcinomas (5-10). Initially, the monoclonal antibody B72.3, prepared against a membraneenriched extract of human breast carcinoma (11), was used to evaluate the expression of the TAG-72 antigen. It has been demonstrated that TAG-72 is not expressed in neural tumors or in adult normal tissues except in secretory endometrium; however, its expression was detected in certain fetal tissues $(12,13)$. Thus, the fact that TAG-72 is positive in many adenocarcinomas while lacking a significant reactivity with normal tissues suggests the potential diagnostic and therapeutic utility for human carcinomas, and has been widely investigated in recent years $(14,15)$.

Earlier studies of TAG-72 expression in prostatic adenocarcinomas have been limited to B72.3 that has a lower affinity than CC49 (16). Several other antibodies such as CC49 and $\mathrm{CC} 83$ have also been developed to detect the TAG-72 antigen (16). Each of these antibodies recognizes a specific epitope on the TAG-72 antigen. Radiolabeled CC49 monoclonal antibody (a second generation, high affinity antibody against TAG-72) has been used in several clinical trials. It showed the best tumor targeting in patients with breast, colon, and prostate cancer (4,17-19). The objective of the present study was to analyze the expression of TAG-72 antigen in a large series of moderate and high-grade human prostatic adenocarcinomas using CC49 monoclonal antibody.

\section{Materials and methods}

Prostatic adenocarcinoma tissues were obtained from 33 patients. The tissue was fixed in $10 \%$ neutral formalin, embedded in paraffin and $5 \mu \mathrm{m}$ sections were stained with 
hematoxylin and eosin for pathological evaluation. The combined Gleason grade and pathological stage was assessed by one of the authors (S.L. Johansson) according to AJCC (20). Additional $5 \mu \mathrm{m}$ thick tissue sections cut from the paraffin block were stained with the monoclonal antibody CC49 for TAG-72 expression by immunohistochemical (IHC) technique with the appropriate positive and negative controls.

The tumor tissue sections on the slide were deparaffinized using EZ-DeWax solution (BioGenex, CA). The slides were kept twice in a series of EZ-DeWax solution for 5-7 min, and then rinsed several times with distilled water. The tissue sections were washed three times with PBS (phosphate buffer saline). The tissue peroxidase activity was blocked by an autoblocker (Research Genetics, AL) for $5 \mathrm{~min}$. Again the tissue samples were washed three times with PBS and incubated with the diluted Vectastain Horse Normal Serum (provided in the kit) in which the secondary antibody was raised, for $20 \mathrm{~min}$ to block the non-specific antigen-antibody immunoreactivity. The samples were incubated overnight at $4^{\circ} \mathrm{C}$ with 1:500 dilution of a stock solution of $2.6 \mathrm{mg} / \mathrm{ml}$ of primary antibody CC49. The IHC reaction was detected by using an $\mathrm{ABC}$ Elite Kit (Vector Laboratories, CA) as per the manufacturer's instructions. A reddish-brown precipitate indicated positive immunoreactivity.

The intensity of immunoreactivity of CC49 with TAG-72 antigen was scored independently by three investigators. Staining intensity was graded on $0-3$ scale i.e., 0 for no staining, 1+ for week immunoreactivity; 2+ for intermediate immunoreactivity and $3+$ for strong immunoreactivity. The extent of the staining was scored as follows: less than $25 \%$ of tumor cells stained (1); $25-50 \%$ of the tumor cells stained positive (2); $50-75 \%$ of the tumor cells stained positive (3) and more than $75 \%$ of the tumor cells stained positive (4). Intensity and extent of staining scores were multiplied with the maximum score being 12 .

\section{Results}

We examined the expression of TAG-72 antigen in 33 specimens of the prostatic adenocarcinomas with CC49 monoclonal antibody by immunohistochemical analysis. Four of the 33 samples did not show any immunoreactivity for unknown reasons. In this study, 73\% (24/33) of the specimens had Gleason grade 7 or higher while $27 \%$ had Gleason grade 6 . Thus, the analyzed samples were moderately (Gleason grade 6) or moderately poorly differentiated (Gleason grade 7) or poorly differentiated (Gleason grade 8-10). Most of the patients had localized disease (stage T2), or an extracapsular extension or an invasion of seminal vesicles (stage T3). Gleason grade, tumor stage and the extent of staining as well as a combined staining score are given in Table I.

Independent of Gleason grade, $<25 \%$ of the tumor cells exhibited immunoreactivity in 10 specimens, $25-50 \%$ in 8 specimens, $50-75 \%$ in 9 cases, while positive staining in $>75 \%$ cell populations was observed in only 2 cases. A heterogeneous staining pattern was observed among the analyzed specimens of prostatic adenocarcinomas either based on the intensity of the staining pattern [coefficient of variation $(\mathrm{CV})=45.5 \%$ ] or the extent of the staining $(\mathrm{CV}=65 \%)$ as detailed in Table I. Furthermore, a remarkable heterogeneity
Table I. TAG-72 expression in 33 specimens of prostatic adenocarcinomas with CC49 antibody by immunohistochemical analysis.

\begin{tabular}{|c|c|c|c|c|c|}
\hline $\begin{array}{l}\text { Specimen } \\
\text { number }\end{array}$ & $\begin{array}{l}\text { Gleasons } \\
\text { grade }\end{array}$ & Stage & $\begin{array}{c}\text { TAG-72 } \\
\text { staining } \\
\text { pattern }\end{array}$ & $\begin{array}{l}\text { Extent of } \\
\text { staining }\end{array}$ & $\begin{array}{c}\text { Total } \\
\text { staining } \\
\text { score }\end{array}$ \\
\hline 1 & 6 & $\mathrm{~T} 2$ & 1 & 4 & 4 \\
\hline 2 & 7 & $\mathrm{~T} 2$ & 2 & 2 & 4 \\
\hline 3 & 7 & T3 & 1 & 1 & 1 \\
\hline 4 & 7 & $\mathrm{~T} 2$ & 1 & 1 & 1 \\
\hline 5 & 6 & $\mathrm{~T} 2$ & 2 & 3 & 6 \\
\hline 6 & 8 & $\mathrm{~T} 2$ & 1 & 1 & 1 \\
\hline 7 & 8 & $\mathrm{~T} 2$ & 0 & 0 & 0 \\
\hline 8 & 7 & $\mathrm{~T} 2$ & 2 & 2 & 4 \\
\hline 9 & 6 & $\mathrm{~T} 2$ & 3 & 3 & 9 \\
\hline 10 & 7 & $\mathrm{~T} 2$ & 1 & 2 & 2 \\
\hline 11 & 7 & $\mathrm{~T} 2$ & 2 & 3 & 6 \\
\hline 12 & 7 & T3 & 2 & 1 & 2 \\
\hline 13 & 7 & $\mathrm{~T} 2$ & 0 & 0 & 0 \\
\hline 14 & 6 & $\mathrm{~T} 2$ & 2 & 1 & 2 \\
\hline 15 & 7 & $\mathrm{~T} 2$ & 1 & 1 & 1 \\
\hline 16 & 9 & $\mathrm{~T} 3$ & 0 & 0 & 0 \\
\hline 17 & 6 & $\mathrm{~T} 2$ & 1 & 3 & 3 \\
\hline 18 & 8 & $\mathrm{~T} 2$ & 1 & 3 & 3 \\
\hline 19 & 7 & $\mathrm{~T} 2$ & 1 & 3 & 3 \\
\hline 20 & 7 & $\mathrm{~T} 2$ & 1 & 2 & 2 \\
\hline 21 & 8 & $\mathrm{~T} 2$ & 1 & 1 & 1 \\
\hline 22 & 9 & $\mathrm{~T} 3$ & 1 & 1 & 1 \\
\hline 23 & 6 & $\mathrm{~T} 2$ & 2 & 3 & 6 \\
\hline 24 & 8 & $\mathrm{~T} 2$ & 2 & 1 & 3 \\
\hline 25 & 6 & $\mathrm{~T} 1$ & 1 & 1 & 1 \\
\hline 26 & 7 & T3 & 2 & 1 & 2 \\
\hline 27 & 8 & $\mathrm{~T} 2$ & 1 & 2 & 2 \\
\hline 28 & 6 & $\mathrm{~T} 2$ & 2 & 1 & 2 \\
\hline 29 & 9 & T3 & 1 & 2 & 3 \\
\hline 30 & 7 & $\mathrm{~T} 2$ & 3 & 4 & 12 \\
\hline 31 & 6 & $\mathrm{~T} 1$ & 0 & 0 & 0 \\
\hline 32 & 8 & $\mathrm{~T} 3$ & 1 & 2 & 2 \\
\hline 33 & 9 & T3 & 1 & 3 & 3 \\
\hline
\end{tabular}

was also observed for stage $\mathrm{T} 2(\mathrm{CV}=86 \%)$ and stage $\mathrm{T} 3$ $(\mathrm{CV}=59 \%)$. The overall heterogeneity pattern within as well as between the stages was on the margin of the significant level. This lack of significance in the present study may be due to too few patients with stage T3 disease.

The localization and expression pattern of the TAG-72 antigen was very similar in all the specimens. Generally, most of the cases (87\%) showed cytoplasmic immunoreactivity of the malignant cells (Fig. 1). Only three specimens revealed 


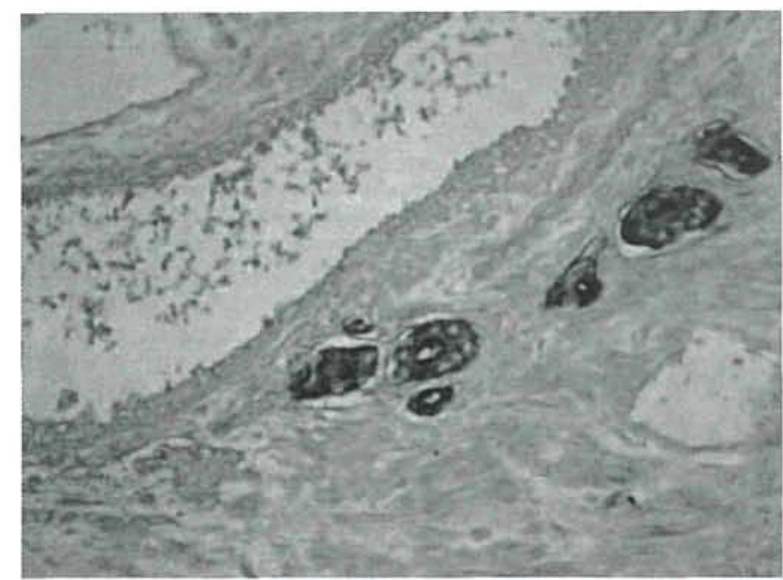

Figure 1. Prostatic adenocarcinoma, Gleason grade 7 , showing a strong positive staining for TAG-72. Note the non-reactive benign gland adjacent to the malignant glands.

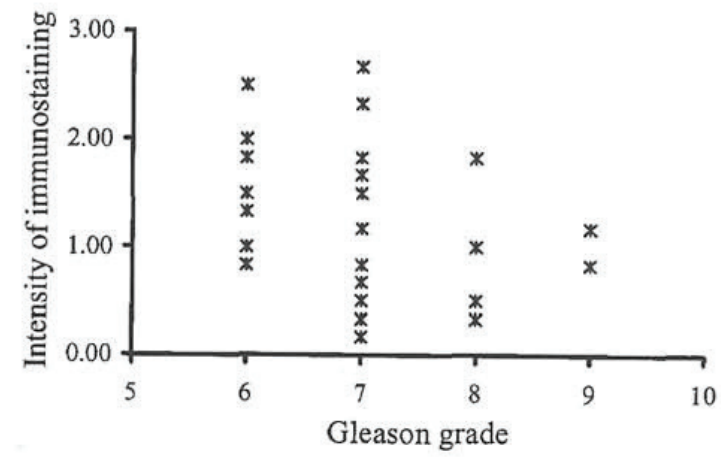

Figure 2. Immunostaining evaluation of TAG-72 antigen expression in prostatic adenocarcinomas.

membrane-bound staining, and two cases showed luminal staining of the malignant cells. The percentage of positively stained cells varied considerably among the specimens. On average, $25-70 \%$ of the tumor cells demonstrated a positive immunoreactivity with CC49 monoclonal antibody. The TAG-72 antigen expression was not detected in any of the stromal cells. However, only a few glandular cells $(<25 \%)$ in the areas of benign prostatic hyperplasia (BPH) showed a very faint granular cytoplasmic staining, while 12 of the 33 specimens were completely negative for CC49 immunostaining. The areas of prostatic intraepithelial neoplasia (PIN) were seen in seven specimens of prostatic adenocarcinomas and showed staining intensities between 1 and 2 . In these areas, the staining pattern was uniform and 5 cases showed immunoreactivity in $25-50 \%$ cells while 2 cases had $50-75 \%$ positive cells.

We evaluated a possible relationship between tumor grade and TAG-72 antigen expression. The correlation between the intensity of staining and the Gleason grade is shown in Fig. 2. Moderately differentiated tumors (Gleason grade 6 and 7) exhibited a higher level of immunoreactivity than poorly differentiated tumors (Gleason grade $>7$ ). There was a significant negative correlation $(r=-0.36, p<0.05)$ of TAG-72 antigen expression with increasing Gleason grade.

\section{Discussion}

The present study aimed to assess the expression of a tumorassociated glycoprotein (TAG-72) in prostate cancer tissue samples. TAG-72 is a high molecular weight glycoprotein of the mucin family, which is expressed on a range of human carcinomas including colorectal, gastric, pancreatic, ovarian, endometrial, breast, non-small cell lung, and prostate (5-10). Altered expression of mucins has been associated with the histopathology of various tumors. TAG-72 may be aberrantly glycosylated in tumors, and hence becoming more attractive for immunotherapeutic studies $(21,22)$. Monoclonal antibody CC49 is the prototype monoclonal antibody of such studies.

In the present study, we observed a heterogeneous immunostaining pattern with CC49 within the prostatic tumor specimens. When positive, the tumors generally showed a cytoplasmic distribution of TAG-72 expression similar to previously published results $(8,10,23-25)$. Tumors that contain the areas of moderate differentiation (Gleason pattern 3) showed a higher tendency for TAG-72 antigen expression as compared to the adjacent poorly differentiated tumors (Gleason pattern 4 or 5). In contrast, in some specimens the moderately differentiated tumor areas also exhibited a very faint staining. Though it is difficult to explain, probably these cells may have lost their antigenicity due to differential glycosylation. We observed a decreased expression pattern of the TAG-72 antigen in poorly differentiated tumors, which may be due to the reduced secretory activity of such tumors. Previous studies also showed an inverse correlation of the prostate specific antigen with Gleason grade (26). It is not possible to compare the exact expression pattern of the TAG-72 antigen because of the lack of well-differentiated specimens and normal tissue samples. Furthermore, we could not correlate our data with the developmental stage since most of the analyzed tumors were stage $\mathrm{T} 2$ and $\mathrm{T} 3$.

In previous studies, a low expression level of the TAG-72 antigen was seen in BPH with B72.3 antibody $(24,27)$. We also observed a very weak and faint staining in the benign epithelium of prostatic adenocarcinomas in $61 \%$ specimens, and in the areas of acute prostatitis. Moderately differentiated tumors (Gleason grade $3+3$ ) had a stronger staining than the benign glandular epithelium. It does not necessarily mean that TAG-72 antigen is absent in the benign epithelium but it may be due to the limitations of the sensitivity of the immunohistochemical technique.

The monoclonal antibody CC49 has already entered clinical trials for radionuclide images and treatment of colon, breast, ovarian and prostate cancer (17-19). These studies have shown the potential of the CC49 monoclonal antibody in identifying the tumor antigen targets such as TAG-72. Recently, an improved approach for therapeutic application has been demonstrated by a genetically engineered tetravalent form of CC49 (28). The results indicate that this tetravalent form of CC49 may be more sensitive in recognizing the TAG72 as a tumor marker in various types of carcinomas including prostatic adenocarcinomas. 
In conclusion, this study demonstrates the expression of the TAG-72 antigen detected with the monoclonal antibody CC49 in malignant cells of prostatic adenocarcinomas, supporting previous studies that TAG-72 may be a potential target for prostatic adenocarcinomas with a CC49 antibody.

\section{Acknowledgements}

This work was supported, in part, by grants from the National Cancer Institute (CA 72274 and CA 88184), the Nebraska Health Department/UNMC Eppley Cancer Center LB 595 and the Program of Nebraska Research Initiative. We thank Dr Schlom Jeffrey (Laboratory of Tumor Immunology and Biology, NCI, MD) for providing the CC49 MAb and Dr Tsukasa Igawa for scoring the intensity pattern of the stained slides as a third observer. Kristi L.W. Berger, Eppley Institute, is greatly acknowledged for her editorial assistance.

\section{References}

1. Parker SL, Tong T, Bolden S and Wingo PA: Cancer statistics, 1996. CA Cancer J Clin 46: 5-27, 1996.

2. Boring CC, Squires TS and Tong T: Cancer statistics, 1993. CA Cancer J Clin 43: 7-26, 1993.

3. Babaian RJ and Lamki LM: Radioimmunoscintigraphy of prostate cancer. Semin Nucl Med 19: 309-321, 1989.

4. Meredith RF, Bueschen AJ, Khazaeli MB, Plott WE, Grizzle WE Wheeler RH, Schlom J, Russell CD, Liu T and LoBuglio AF: Treatment of metastatic prostate carcinoma with radiolabeled antibody CC49. J Nucl Med 35: 1017-1022, 1994.

5. Johnston WW, Szpak CA, Lottich SC, Thor A and Schlom J: Use of a monoclonal antibody (B72.3) as a novel immunohistochemical adjunct for the diagnosis of carcinomas in fine needle aspiration biopsy specimens. Hum Pathol 17: 501-513, 1986.

6. MacLean GD, Reddish M, Koganty RR, Wong T, Gandhi S, Smolenski M, Samuel J, Nabholtz JM and Longenecker BM: Immunization of breast cancer patients using a synthetic sialylTn glycoconjugate plus Detox adjuvant. Cancer Immunol Immunother 36: 215-222, 1993.

7. Myers RB, Meredith RF, Schlom J, LoBuglio AF, Bueschen AJ, Wheeler RH, Stockard CR and Grizzle WE: Tumor associated glycoprotein-72 is highly expressed in prostatic adenocarcinomas. J Urol 152: 243-246, 1994.

8. Nuti M, Teramoto YA, Mariani-Costantini R, Hand PH, Colcher D and Schlom JA: Monoclonal antibody (B72.3) defines patterns of distribution of a novel tumor-associated antigen in human mammary carcinoma cell populations. Int J Cancer 29: $539-545,1982$.

9. Nuti M, Mottolese M, Viora M, Donnorso RP, Schlom J and Natali PG: Use of monoclonal antibodies to human breasttumor-associated antigens in fine-needle aspirate cytology. Int J Cancer 37: 493-498, 1986.

10. Stramignoni D, Bowen R, Atkinson BF and Schlom J: Differential reactivity of monoclonal antibodies with human colon adenocarcinomas and adenomas. Int J Cancer 31: 543-552, 1983.

11. Colcher D, Hand PH, Nuti M and Schlom J: A spectrum of monoclonal antibodies reactive with human mammary tumor cells. Proc Natl Acad Sci USA 78: 3199-3203, 1981.

12. Thor A, Ohuchi N, Szpak CA, Johnston WW and Schlom J: Distribution of oncofetal antigen tumor-associated glycoprotein72 defined by monoclonal antibody B72.3. Cancer Res 46: 3118-3124, 1986.

13. Thor A, Viglione MJ, Muraro R, Ohuchi N, Schlom J and Gorstein F: Monoclonal antibody B72.3 reactivity with human endometrium: a study of normal and malignant tissues. Int $\mathrm{J}$ Gynecol Pathol 6: 235-247, 1987.
14. Guadagni F, Roselli M, Amato T, Cosimelli M, Mannella E, Tedesco M, Grassi A, Casale V, Cavaliere F and Greiner JW: Clinical evaluation of serum tumor-associated glycoprotein-72 as a novel tumor marker for colorectal cancer patients. J Surg Oncol Suppl 2: 16-20, 1991.

15. Myers RB, Schlom J, Srivastava S and Grizzle WE: Expression of tumor-associated glycoprotein 72 in prostatic intraepithelial neoplasia and prostatic adenocarcinoma. Mod Pathol 8: 260-265, 1995.

16. Muraro R, Kuroki M, Wunderlich D, Poole DJ, Colcher D, Thor A, Greiner JW, Simpson JF, Molinolo A and Noguchi P: Generation and characterization of B72.3 second generation monoclonal antibodies reactive with the tumor-associated glycoprotein 72 antigen. Cancer Res 48: 4588-4596, 1988.

17. Meredith RF, Khazaeli MB, Plott WE, Grizzle WE, Liu T, Schlom J, Russell CD, Wheeler RH and LoBuglio AF: Phase II study of dual 131I-labeled monoclonal antibody therapy with interferon in patients with metastatic colorectal cancer. Clin Cancer Res 2: 1811-1818, 1996.

18. Meredith RF, Khazaeli MB, Macey DJ, Grizzle WE, Mayo M, Schlom J, Russell CD and LoBuglio AF: Phase II study of interferon-enhanced 131I-labeled high affinity CC49 monoclonal antibody therapy in patients with metastatic prostate cancer. Clin Cancer Res 5: 3254s-3258s, 1999.

19. Slovin SF, Scher HI, Divgi CR, Reuter V, Sgouros G, Moore M, Weingard K, Pettengall R, Imbriaco M, El-Shirbiny A, Finn R, Bronstein J, Brett C, Milenic D, Dnistrian A, Shapiro L, Schlom J and Larson SM: Interferon-gamma and monoclonal antibody 131I-labeled CC49: outcomes in patients with androgenindependent prostate cancer. Clin Cancer Res 4: 643-651, 1998.

20. Fleming ID, Cooper JS, Henson DE, Hutter RVP, Kennedy BJ, Murphy GP, O'Sullivan B, Sobin LH and Yarbro JW: AJCC Cancer staining manual. 5th edition. Lippincott Williams and Wilkins, Philadelphia, pp1-294, 1997.

21. O'Boyle K, Goya V, Zuckier LH, Chun S and Bhargava K: Expression of human tumor mucin-associated carbohydrate epitopes, including sialylated $\mathrm{Tn}$, and localization of murine monoclonal antibodies $\mathrm{CC} 49$ and $\mathrm{B} 72.3$ in a syngeneic rat colon carcinoma model. J Immunother 16: 251-261, 1994.

22. Sparano JA and O'Boyle K: The potential role for biological therapy in the treatment of breast cancer. Semin Oncol 19: 333-341, 1992.

23. Lyubsky S, Madariaga J, Lozowski M, Mishriki Y, Schuss A, Chao S and Lundy JA: Tumor-associated antigen in carcinoma of the pancreas defined by monoclonal antibody B72.3. Am J Clin Pathol 89: 160-167, 1988.

24. Mazur MT and Shultz JJ: Prostatic adenocarcinoma. Evaluation of immuno-reactivity to monoclonal antibody B72.3. Am J Clin Pathol 93: 466-470, 1990.

25. Ohuchi N, Simpson JF, Colcher D and Schlom J: Complementation of anti-CEA and anti-TAG-72 monoclonal antibodies in reactivity to human gastric adenocarcinomas. Int $\mathrm{J}$ Cancer 40: 726-733, 1987

26. Partin AW, Carter HB, Chan DW, Epstein JI, Oesterling JE, Rock RC, Weber JP and Walsh PC: Prostate specific antigen in the staging of localized prostate cancer: influence of tumor differentiation, tumor volume and benign hyperplasia. J Urol 143: 747-752, 1990 .

27. Badalament RA, Burgers JK, Petty LR, Mojzisik CM, Berens A, Marsh W, Hinkle GH and Martin EW: Radioimmunoguided radical prostatectomy and lymphadenectomy. Cancer 71: 2268-2275, 1993.

28. Goel A, Colcher D, Baranowska-Kortylewicz J, Augustine S, Booth BJ, Pavlinkova G and Batra SK: Genetically engineered tetravalent single-chain $\mathrm{Fv}$ of the pancarcinoma monoclonal antibody CC49: improved biodistribution and potential for therapeutic application. Cancer Res 60: 6964-6971, 2000. 